\title{
Genomic alteration in hereditary colorectal patients without mutations in mismatch repair genes
}

\author{
Rolando AR Villacis ${ }^{1 *}$, Érika MM Santos ${ }^{2}$, Benedito M Rossi ${ }^{3}$, Dirce M Carraro', Luiz P Kowalski ${ }^{4}$, Silvia R Rogatto ${ }^{1,5}$ \\ From São Paulo Advanced School of Comparative Oncology \\ Águas de São Pedro, Brazil. 30 September - 6 October 2012
}

\section{Background}

Lynch Syndrome (LS) is the most common hereditary syndrome of colorectal cancer (CRC), caused by mutations in mismatch repair (MMR) genes. It is estimated that $50 \%$ of families classified according Amsterdam criteria not show germline mutations in MMR genes. These findings suggest that other genetic or epigenetic factors are associated with predisposition to CRC.

\section{Materials and methods}

It was evaluated germline copy number variations (CNVs) in 57 patients with LS (Amsterdam Criteria), but without pathogenic mutations in MMR genes, by array CGH using the $4 \times 180 \mathrm{~K}$ platform (Agilent Technologies). Genomic data were extracted with Feature Extraction software and analyzed using Genomic Workbench software, statistical algorithm ADM-2 and threshold of 6.7.

\section{Results}

It was found $252 \mathrm{CNVs}(4.4 \pm 3.6 \mathrm{CNVs} /$ individual $)$, including 104 genomic gains and 148 losses. After comparison with a reference group, composed of 100 healthy Brazilian women (Krepischi et al., 2012) and the Database of Genomic Variants (DGV-hg18), 106 rare CNVs were identified in 41 cases and 10 new rare CNVs in six cases. Four rare CNVs, of the same size, were detected in at least three cases: 1q21.1, 7p22.3, 11q13.2 and 15q11.2. Four patients had new rare CNVs mapped at 7 p22.3. In $7 \mathrm{p} 22.3$ and 15q11.2.

\section{Conclusions}

Putative candidate genes mapped on $7 \mathrm{p} 22$ are suggestive to be associated with hereditary predisposition to CRC. The relatives of those probands are being evaluated to

\footnotetext{
* Correspondence: andrevillacis@yahoo.com.br

${ }^{1}$ CIPE - AC Camargo Cancer Hospital, São Paulo, SP, Brazil

Full list of author information is available at the end of the article
}

confirm the segregation of the most important alterations and their association with CCR predisposition.

\section{Financial support \\ FAPESP and CAPES.}

\begin{abstract}
Author details
${ }^{1}$ CIPE - AC Camargo Cancer Hospital, São Paulo, SP, Brazil. ²Department of Pelvic Surgery, AC Camargo Cancer Hospital, São Paulo, SP, Brazil. ${ }^{3}$ Department of Oncogenetic, Barretos Cancer Hospital, Barretos, SP, Brazil. ${ }^{4}$ Department of Head and Neck Surgery and Otorhinolaryngology, AC Camargo Cancer Hospital, São Paulo, SP, Brazil. ${ }^{5}$ Department of Urology, Faculty of Medicine, UNESP, Botucatu, SP, Brazil.
\end{abstract}

Published: 4 April 2013

doi:10.1186/1753-6561-7-S2-O5

Cite this article as: Villacis et al:: Genomic alteration in hereditary

colorectal patients without mutations in mismatch repair genes. BMC

Proceedings 2013 7(Suppl 2):05.

Submit your next manuscript to BioMed Central and take full advantage of:

- Convenient online submission

- Thorough peer review

- No space constraints or color figure charges

- Immediate publication on acceptance

- Inclusion in PubMed, CAS, Scopus and Google Scholar

- Research which is freely available for redistribution

Submit your manuscript at www.biomedcentral.com/submit C Biomed Central 